\title{
A View of Forest Pathology Research in Canada
}

by

Denis Lachance ${ }^{1}$

\begin{abstract}
Losses due to diseases are an important part of forest pest depletion, therefore much is expected from forest pathology research. Examples of recent accomplishments in forest disease protection include a vastly increased knowledge in the field of root and butt rots as well as in control methodologies and in the predictability of such problems; the development of control strategies for scleroderris canker through increased surveys, improved diagnostic methodologies and new control techniques; the establishment of white pine blister rust hazard zones; and the publication of user-friendly technical bulletins. As the pool of forest pathology researchers has changed little in recent years, the task ahead is enormous when compared to expectations. However, acquired knowledge, the application of new technologies, and the more common acceptance of the integrated pest management (IPM) concept should allow for significant strides forward in forest disease control. Finally, it is suggested that forest pathologists take the lead in promoting a concept of forest health to promote better integration of forest disease protection with forest stand productivity and survival.
\end{abstract}

\section{Résumé}

On attend beaucoup de la recherche en pathologie forestière pour parvenir à réduire les pertes dues aux maladies dans les forêts. Comme exemples de réalisations récentes dans la protection contre les maladies des arbres mentionnons l'augmentation substantielle des connaissances dans le domaine des caries des racines et des souches ainsi que dans les méthodes de lutte et de prédiction de ces problèmes; la mise au point de stratégies de lutte contre le chancre scléroderrien avec de meilleurs relevés, l'amélioration des techniques de diagnostic et l'utilisation de méthodes plus efficaces de lutte; la description de zones de risques d'infections par la rouille vésiculeuse du pin; et la publication d'excellents bulletins de vulgarisation scientifique. Avec un potentiel de recherche en pathologie forestière pratiquement inchangé depuis plusieurs années, la tâche à accomplir est imposante si l'on veut satisfaire quelque peu les attentes dans le domaine. Par contre, les connaissances nouvelles, l'utilisation de nouvelles technologies et la mise en application plus courante du concept de la lutte intégrée contre les ravageurs devraient permettre d'autres progrès importants en pathologie forestière. On conclut en suggérant que les pathologistes forestiers prennent l'initiative dans la promotion du concept de santé des forêts, afin de pouvoir bien concilier la protection contre les maladies avec les objectifs de vigueur et de productivité des forêts.

\section{Introduction}

The forest industry is of extreme importance to the economy and the social welfare of Canada. The forest resource of Canada covers about $45 \%$, or 453 million ha, of the total area of the country. About $62 \%$ of the 398 million ha of inventoried forest land is considered productive and suitable for supporting industrial forest (Forestry Canada 1988). In 1987, these forests supported an industry that produced $\$ 38.3$ billion of goods with a net foreign exchange totalling $\$ 18.3$ billion, a greater contribution to Canada's economy than the combined earnings of agriculture, fisheries, mining, and fuels (Canadian Institute of Forestry 1989). The forest industry also provides direct and indirect employment for about 840000 Canadians.

\footnotetext{
Research Scientist, Laurentian Forestry Centre, Forestry Canada, Quebec Region, Sainte-
} Foy, Quebec
Even if the forest is renewable, it is not inexhaustible. Cutting, overcutting, at times no or mismanagement, forest pests (including insects, diseases and fires), and recently air pollution, may all have a negative effect on growth and thus on the overall productivity of the forest. This is today's situation without considering the threat of climate change that may conceivably displace and dramatically change whole forest types. Actions to counter any of these depletion factors are urgently needed.

The Canadian Council of Forest Ministers looked closely at this situation a few years ago and it endorsed "A National Forest Sector Strategy for Canada", (Canadian Council of Forest Ministers 1987). Forest protection was an important concern of the Council. "Failure to invest in protection will jeopardize future benefits from the forest. Furthermore, the level of protection should be appropriate to the value of the resources and the level of investment in its management." 
Recently, the CIF published its "Policy on Integrated Forestry Pest Management"' (CIF 1989). In addition to supporting the forest pest protection recommendations contained in the national forest sector strategy, the Institute stresses the need to integrate management and control measures: "The Institute supports integrated use of carefully executed and environmentally conscious pest management practices where they are required to achieve accepted forest production goals". It also supports an increase in integrated pest management training in all university and technical forestry schools in Canada.

Large volumes of wood fibre could certainly be harvested from the forests through increased protection and salvage. For example, the most recent report on insect and disease losses made by the Forest Insect and Disease Survey Unit of Forestry Canada estimates an average depletion of close to 110 million $\mathrm{m}^{3}$ of wood annually, with diseases accounting for about $42 \%$ of the losses (Canadian Forestry Service 1982). These estimates are conservative because only the losses owing to important pests were evaluated. But can research in forest pathology provide the knowledge and the means required to prevent or substantially reduce this lost depletion?

\section{What is Forest Pathology?}

A simple definition is: "Forest pathology is the branch of botanical science that deals with diseases of forest trees for the purpose of preventing or controlling such diseases" (Boyce 1961). The question then arises "Can we prevent or control forest diseases today?"' The answer is yes. But it has to be qualified. We have acquired the knowledge to control and prevent partly or completely many diseases, but to do so economically opens the door to discussion. Also, we may ask when or to what extent a disease is controlled, because we are dealing with changing living organisms and a changing environment while our interests, and thus our needs, are also rapidly changing. In 1983, Whitney et al. published "Impact and Control of Forest Diseases in Canada", which was based on a report prepared in 1982 by a committee that had reviewed the forest pathology research program of Forestry Canada (formerly the Canadian Forestry Service (CFS)) with the aim of improving forest productivity in Canada. The information gathered during this review was not restricted to CFS activities, and as the authors state in their report: "The sample was considered to represent a cross-section of opinion of forest pathologists and forest managers in Canada". The article presents a relatively complete view of research accomplishments and of research needs in forest pathology in Canada up to 1982. This article concentrates on the years 1982 to 1989 inclusive.

\section{Recent Research Accomplishments}

Pathology research accomplishments made during the last eight years have not revolutionized forest protection nor did they greatly increase overall forest productivity. However, increases in knowledge and improvements in control measures have been made in some fields of forest pathology and some trends in research and development have become more visible. Examples are given below.

\section{Root and Butt Rots}

Research on root and butt rots has reached maturity in recent years. This has always been a very difficult, and for many, a somewhat unattractive area of research. But good and patient work has been going on and this effort seems to have resulted in a much better knowledge of the effect of these rots on forest productivity, greater knowledge of the spread pattern of some causal organisms, and even the development of predictive capabilities of spread and consequently of management alternatives. Examples of this progress are found in recent articles by Whitney $(1988,1989)$ and Whitney and MacDonald (1985) on the identification and importance of major root rots, and on the effect of the causal organisms on spruce and fir, particularly in Ontario. In western Canada, articles by Bloomberg (1983a, 1983b, 1987) and Bloomberg et al. (1980a, 1980b) bring the knowledge on Phellinus weirii root rot one step further, offering capabilities of a simulation model for predicting disease spread and effect. In eastern Canada, an extensive study of stem decays of conifers in Newfoundland, involving the federal and provincial governments and industry, is concluding (Can. For. Serv. 1988).

Across Canada, and across the world, forest pathologists are deciphering the local Armillaria root rot situation as recent information has revealed the existence of distinct biological species (Anderson and Ulrich 1979, Anderson 1986) of this widespread and destructive fungus. What was until recently known as $A$. mellea is now described as the $A$. mellea complex. Clearly defined biological species of Armillaria are now known. With this new information comes a great potential for prediction of impact and thus possible control of this root rot, because these species often have a clearly defined distribution in the forest as well as distinctive pathogenetic capacities. Several recent Canadian articles deal with this subject (Morrison et al. 1985, Berube and Dessureault 1988, 1989, Blenis et al. 1988, and Dumas 1988). The positive effect of this research could be particularly important in an integrated pest management (IPM) program related to reforestation.

\section{Scleroderris Canker}

Scleroderris canker has been a worrisome and stressful problem across Canada in the early to mid-1980s. This disease was already causing much damage in young pine plantations in eastern Canada when a more destructive race (called the European race) of the causal fungus was discovered in New York State in 1976 (Dorworth and Krywienczyk 1975, Dorworth et al. 1977). It was infesting and even killing mature pine stands within 3-4 years after infection. Canadian forest pathologists were asked by forest managers and plant quarantine personnel whether this new race would come into Canada and what to do if it did. This problem was as new and unexpected for forest pathologists as it was for managers. The identification of the "race" was uncertain at that time because the techniques for identifying it were cumbersome, lengthy, and not completely reliable.

Research on race identification technique was accelerated at Great Lakes Forestry Centre (GLFC) (Dorworth et al. 1982) and initiated at Laurentian Forestry Centre (LFC) (Benhamou et al. 1984). Special surveys were begun across Canada by the Forest Insect and Disease Survey (FIDS) unit of Forestry Canada to detect the disease (i.e. the new race of the fungus) and possibly eradicate the pathogen if found.

The first such infection centre was found in southern Quebec in 1978 (Lachance 1979). Disease development was light in this plantation. Complete sanitation of the plantation was done with the hope of eradicating the infection. Additional surveys in the area located nine more infected plantations which were also cleaned of visible disease material. Close 
monitoring during the subsequent years suggested successful eradication as no further infection centers were found in and around these plantations. The European race of the fungus was subsequently found in Newfoundland (Singh et al. 1980) and in New Brunswick (Magasi 1982), and then on a large scale, again in Quebec (Laflamme and Lachance 1987). Meanwhile, research on means of differentiating races of the fungus carried out in Ontario and Quebec was productive. The reliability of serological testing was improved while a new identification method, using electrophoresis, was developed (Ouellette et al. 1988). Electrophoresis has become the standard test for race identification.

Further research on causal fungal determination (Petrini et al. 1989) and disease control (Bergdahl and Ward 1984, Laflamme 1988) led to an integrated management system whereby disease detection, identification and control measures are synchronized, and apparently limit or reduce greatly the damage to pine plantations. As in most cases when biological organisms are involved, however, it is difficult to evaluate the role of other contributing factors, such as reduction in the number of planted pine seedlings and the possible effects of unfavourable weather conditions, in the apparently good control of the disease in recent years.

\section{Other Advances}

There have been other advances in forest pathology research (Rishbeth 1987). Some are the result of many years of research to understand a problem and finally to come up with a plan of action. Examples would be the establishment of predictive and somewhat preventive procedures, such as white pine blister rust hazard zones (Hunt 1983, Gross 1985, Lavallée 1986), which allow the manager to identify areas of sensitivity before planting specific species and take the necessary preventive measures if the susceptible species is planted. Control measures for blister rust have also been improved (Hunt et al. 1985). The production of highly informative and relatively practical bulletins and videotapes, such as "The Hidden Enemy" (Whitney 1988) on root rots, is another example of applied pathology research in recent years.

In a short paper, it is difficult to mention or evaluate properly all the recent progress in forest pathology research in Canada. Increases in knowledge, new technology development and applications are processes. Although breakthroughs or events that appear like breakthroughs sometimes occur, often we may simply be seeing the results of favourable circumstances that put into proper perspective several bits of knowledge and technology acquired gradually through individual research efforts.

\section{The Research Pool Today}

\section{Active Forest Pathologists}

Using the Whitney et al. (1983) article as a starting point, I recently canvassed 10 leading forest pathologists covering all regions of Canada to determine the number of forest pathologists devoting a major portion of their time to research today compared with 10 years ago (Table 1). Apparently the numbers have not changed greatly, but there has been a noticeable shift from basic laboratory research to highly applied field studies. This change appears to be mainly the result of a relatively recent decision by the British Columbia Forest Service (Forest Health Division) to have a forest pathologist in each of their seven regions/districts. Their ranks cover a wide range of training and they are involved mainly with
Table 1. The number of active* forest pathologists in research in Canada

\begin{tabular}{|c|c|c|c|c|c|}
\hline Provinces or Regions & Institutions & Fall 1985 & & \multicolumn{2}{|c|}{ Fall 1979} \\
\hline British Columbia & $\begin{array}{l}\text { Government } \\
\text { Universities }\end{array}$ & 17 & 1 & 13 & 1 \\
\hline Prairies & $\begin{array}{l}\text { Government } \\
\text { Universities }\end{array}$ & 2 & 2 & 3 & 1 \\
\hline Ontario & $\begin{array}{l}\text { Government } \\
\text { Universities }\end{array}$ & 6 & 2 & 8 & 2 \\
\hline Quebec & $\begin{array}{l}\text { Government } \\
\text { Universities }\end{array}$ & 4 & 1 & 5 & 1 \\
\hline Maritimes & $\begin{array}{l}\text { Government } \\
\text { Universities }\end{array}$ & 1 & 1 & 2 & 1 \\
\hline Newfoundland & $\begin{array}{l}\text { Government } \\
\text { Universities }\end{array}$ & 2 & 0 & 3 & 0 \\
\hline Total & & 32 & 7 & 34 & 6 \\
\hline
\end{tabular}

- Excludes forest pathologists by training or by title who are not currently active or closely involved with research - basic or applied.

site specific operational problems. Hopefully, this will result in significant acquisitions of knowledge in field pathology.

A concurrent decrease occurred, however, in the number of traditional forest pathology researchers in government institutions, thus the apparent stability in the research pool may not be satisfactory. The need for new knowledge and new control measures in forest pathology is increasing and becoming more pressing while the number of researchers is not growing proportionately. This situation must also be analyzed in the light of the great decrease of researchers in forest pathology that occurred during the 'seventies, particularly within Forestry Canada. Questions are being asked about a similar situation occurring in the United States (Kelman 1987).

\section{Publications}

To see whether there had been noticeable changes in the number or in the subjects of articles published, I surveyed all the forest-pathology-related articles in the Canadian Journal of Forestry Research from 1981 to 1989 (Table 2). So that my selection would be relatively uniform, I included only those that dealt with or that were related to diseases or to the health of trees. I excluded articles dealing with modified growth rates, or strictly with general tree or stand vigour. It was generally difficult to classify an article in one field only; however, I based my decision on the main object of the paper. For example, an article was classified in epidemiology if its main concern was the reaction of the biological causal agent to surrounding conditions; to disease-insect-environment complexes if more than one causal agent seemed to be involved; and to environmental damage if no living causal agent was dominant.

The overall forest pathology research output does not seem to have changed significantly. Also, the proportion of articles by Canadian authors has remained fairly high in recent years compared with the early eighties. The survey also suggests increasing interest in biological control (for diseases), disease-insect-environment complexes, and genetics and disease resistance, although admittedly the supporting data are skimpy. Relative to the number of pages printed, the number of articles published yearly has remained stable or has slightly decreased. In the United States, the journal Plant Disease, published by the American Phytopathological Society, has noted a decline in recent years in the use of its 
Table 2. Number of articles in forest pathology published in the Canadian Journal of Forestry Research, from 1981 through 1989

\begin{tabular}{|c|c|c|c|c|c|c|c|c|c|}
\hline $\begin{array}{l}\text { Forest pathology } \\
\text { related topics }\end{array}$ & 1981 & 1982 & 1983 & 1984 & 1985 & 1986 & 1987 & 1988 & $1989+$ \\
\hline $\begin{array}{l}\text { Control, including } \\
\text { biological control }\end{array}$ & 0 & 1 & 0 & 0 & 1 & 2 & 1 & 1 & 1 \\
\hline $\begin{array}{l}\text { Disease-insect- } \\
\text { environment complex }\end{array}$ & 0 & 0 & 0 & 0 & 2 & 1 & 1 & 2 & 0 \\
\hline Abiotic problems & 3 & 3 & 1 & 2 & 1 & 4 & 4 & 1 & 3 \\
\hline Epidemiology & 3 & 4 & 4 & 2 & 4 & 5 & 0 & 5 & 4 \\
\hline $\begin{array}{l}\text { Evaluation of damage } \\
\text { and losses }\end{array}$ & 3 & 3 & 1 & 3 & 5 & 4 & 5 & 4 & 2 \\
\hline $\begin{array}{l}\text { Genetics and disease } \\
\text { resistance }\end{array}$ & 0 & 0 & 0 & 1 & 0 & 3 & 3 & 1 & 1 \\
\hline $\begin{array}{l}\text { Host-parasite } \\
\text { relationships }\end{array}$ & 0 & 3 & 0 & 1 & 1 & 6 & 1 & 4 & 1 \\
\hline Mycorrhizae & 2 & 2 & 1 & 0 & 1 & 0 & 4 & 0 & 1 \\
\hline $\begin{array}{l}\text { Seed and nursery } \\
\text { diseases }\end{array}$ & 1 & 0 & 2 & 2 & 0 & 0 & 0 & 3 & 1 \\
\hline $\begin{array}{l}\text { Others (predisposi- } \\
\text { tion, survey methods, } \\
\text { descriptions, } \\
\text { modeling, etc.) }\end{array}$ & 2 & 7 & 1 & 0 & 1 & 1 & 2 & 2 & 5 \\
\hline Total & 14 & 23 & 10 & 11 & 16 & 26 & 21 & 24 & 19 \\
\hline $\begin{array}{l}\text { Articles with at } \\
\text { least one Canadian aut } \\
(\% \text { of yearly total) }\end{array}$ & $\begin{array}{l}5(35.7 \%) \\
\text { nor }\end{array}$ & $4(17.4 \%)$ & $2(20.0 \%)$ & $4(36.4 \%)$ & $6(37.5 \%)$ & $10(38.5 \%)$ & $8(38.0 \%)$ & $13(54.2 \%)$ & $5(26.3 \%)$ \\
\hline $\begin{array}{l}\text { Tota number of } \\
\text { pages per journal volur }\end{array}$ & 860 & 1039 & 1270 & *954 & 1201 & 1397 & 1630 & 1662 & $1500+$ \\
\hline
\end{tabular}

- The journal goes metric: Page Size Increases.

+ Partial Results: December Issue not included.

pages by phytopathologists (Sinclair 1989). One explanation suggested is the increasing proportion of reports submitted by plant pathologists to diverse journals of applied research and of allied sciences.

\section{Looking Ahead}

Is there a bright future for forest pathology in Canada? Yes, but this future may not be as spectacular as it will be important and useful. Forest protection and integrated pest management are seen as very real means of reducing overall forest depletion and even of increasing forest productivity. On the other hand, when we talk about integration, we have to think about a new or expanded concept of protection. Here, ironically, to be at the forefront of forest protection, forest pathology in its strict sense may have to take a lower profile. The classical "forest disease" concept should now be replaced by a "forest health" concept that includes, in addition to loss of growth, an increase in productivity and in disease resistance through improved health! This concept should also be flexible enough to include stand disturbances as a positive reaction to some stresses.

Cowling and Horsfall (1980) defined disease "as an alteration of normal function induced by continuous irritation". This appears to be a condensed version of Bateman's (1978) definition in the same treatise series where the author says that the plant becomes diseased as opposed to healthy when the alteration goes "beyond the range of easy tolerance" of the plant. We need to keep in mind a much broader view than the tolerance of an individual plant. With today's advances in knowledge and technology (e.g. gene manipulation), with forest managers' expectations (e.g. IPM), and with forecasted severe forest stresses and consequent disturbances (e.g. greenhouse effects, climate change), there is clearly an urgent need for forest health experts, in addition to traditional forest pathologists. Recently, the Society of American Foresters chose as its national convention theme "Healthy Forests, Healthy World". This idea is not new, as there have been previous (Tammen and Wood 1977, Browning 1983) and still are discussions on this subject (Lockwood 1985). A degree in plant health has been suggested for the practitioner in plant pathology. As a group, however, forest pathologists are likely the most apt to fill that task. This was also suggested by Browning (1983) when he stated that: "Many disciplines have a rightful claim to a part of plant health using my broad definition, but the philosophy of the healthy plant belongs to plant pathology (Sic.)".

The need to promote a unifying concept of forest health is also apparent in the scientific literature. As I mentioned above, while surveying articles in forest pathology in the Canadian Journal of Forest Research, I selected only those that dealt directly with diseased plants; I then excluded articles that dealt with modification of growth rates or with tree or stand vigour. The division was difficult, and by doing so I had to set aside several articles dealing with tree health. Examples are: "Effects of different vesicular-arbuscular mycorrhizal fungi on growth of Fraxinus americana' (Furlan et al. 1983); "White ash seedling growth response to ozone and simulated acid rain" (Chappelka and Chevone 1986); "Effect of aluminum on the growth of sugar maple in solution culture" (Thorton et al. 1986); "Loblolly pine seedling root anatomy 
and iron accumulation as affected by soil waterlogging' (McKevlin et al. 1987); and "Radial trends in cation ratios in tree rings as indicators of the impact of atmospheric deposition on forests" (Bondietti et al. 1989). These articles show how or to what extent plants or forests are affected by given factors but with no reference to them as being diseased. In a context of tree or forest health, defining the thin line where a plant becomes diseased is hardly necessary. One could only say for most situations "the healthier the better!", or its corollary "the less healthy a plant or a forest, the more acute the problem".

Beside promoting or acting within this concept of forest health, forest pathologists will have to spend much time on evaluating the effect of diseases or disturbances on the forest ecosystems. Thus, survey and impact evaluation methodologies will have to be developed or improved, as well as the modelling of ecosystems to develop predictive tools, such as the Geographical Information Systems (GIS) or other expert systems. More knowledge of disease-insect-environment complexes is a must for good prediction. Disease or problem diagnosis should also be improved through immuno-assays utilizing polyclonal and/or monoclonal antibodies and through DNA probe technology.

Control, whether direct or through IPM, will remain a primary objective of forest health protection. Research on biological control should be accelerated. Studies will have to be carried out on antagonism, competitive inhibition and hyperparasitism either between microorganisms or between microorganisms and plants as well as on ecological factors that affect or regulate these interactions.

Biotechnology will come into play (Hubbes 1987). Beside the aspects mentioned above in relation to problem diagnosis, molecular genetics should help to improve disease resistance and forest productivity and even the capability of trees to survive and grow well in modified environmental conditions.

Finally, society in general and forest managers in particular must realize and accept that diseased or relatively unhealthy trees or forests are and will always be part of the normal forest ecosystems. And all the more so, when man causes unnatural disturbances, either voluntarily through exploitation and management, or partly non-voluntarily through air or other environmental pollution. Forest pathologists and economists must work together to define an acceptable "disease threshold", a concept required in any IPM system, where biological life has enough room to both maintain relatively healthy ecosystems while, at the same time, being able to recycle its nutrients and adjust its ecosystems to the environmental constraints to continue to perpetuate itself.

\section{References}

Anderson, J.B. 1986. Biological species of Armillaria in North America: redesignation of groups IV and VIII and enumeration of voucher strains for other groups. Mycologia 78:837-839.

Anderson, J.B. and R.C. Ulrich. 1979. Biological species of Armillaria mellea in North America. Mycologia 71:402-414.

Bateman, D.F. 1978. The Dynamic Nature of Disease. Pages 53-83. In. Plant Disease, an Advanced Treatise. Vol. III. J.G. Horsfall and E.B. Cowling Eds. Academic Press. N.Y. 487 pp.

Benhamou, N., G.B. Ouellette, A. Asselin and E. Maicas. 1984. The use of polyacrylamide gel electrophoresis for rapid differentiation of Gremmeniella abietina isolates. Pages 68-76 In. P.D. Manion (Ed.) Scleroderris Canker of Conifers; Proc. International symp. June 21-24, 1983. Syracuse, N.Y. Martinus NijhoffDr.W. Junk Publishers. The Hague, Netherlands. 273 p.
Bergdah, D.R. and T.M. Ward. 1984. Pruning as a silvicultural tool in the management of Pinus resinosa infected with Gremmeniella abietina. Pages 166-176 In. P.D. Manion (Ed.) Scleroderris Canker of Conifers; Proceeding of an international symposium, June $21-24,1983$. Syracuse, N.Y. Martinus NijhoffDr. W. Junk Publishers. The Hague, Netherlands. 273 p.

Bérubé, J.A. and M. Dessureault. 1988. Morphological characterization of Armillaria ostoyae and Armillaria sinapina sp. nov. Can. J. Bot. 66:2027-2034

Bérubé, J.A. and M. Dessureault. 1989. Morphological studies of the Armillaria mellea complex: two new species, A. gemina and A. calvescens. Mycologia 81:216-225.

Blenis, P.V., M.S. Mugala, Y. Hiratsuka and K.I. Mallett. 1988. Soil type and host species affect root rot caused by Alberta isolates of the Armillaria mellea complex. Can. J. Plant Pathol. 10:361 (Abstr.).

Bloomberg, W.J. 1983a. A ground survey method for estimation loss caused by Phellinus weirii root rot. III. Simulation of disease spread and impact. Can. For. Serv. Pacific For. Res. Centre, Victoria, B.C. Rep. BC-R-7. 24 p

Bloomberg, W.J. 1983b. A ground survey method for estimating loss caused by Phellinus weirii root rot. IV. Multiple-disease recording and stratification by infection intensity. Can. For. Serv. Pacific For. Res. Centre, Victoria, B.C. Rep. BC-R-8. 16 p.

Bloomberg, W.J. 1987. Computers in forest disease research, application and technology transfer. Can. J. Plant Pathol. 9: 334-342.

Bloomberg, W.J., P.M. Cumberbirch and G.W. Wallis. 1980a. A ground survey method for estimating loss caused by Phellinus weirii. I. Development of survey design. Can. For. Serv. Pacific For. Res. Cent., Victoria, B.C. Rep. BC-R-3. 24 p.

Bloomberg, W.J., P.M. Cumberbirch and G.W. Wallis. 1980b. A ground survey method for estimating loss caused by Phellinus weirii root rot. II. Survey procedures and data analysis. Can. For. Serv. Pacific For. Res. Cent., Victoria, B.C. BC-R-4. 44 p.

Bondietti, E.A., C.F. Baes III, and S.B. McLaughlin. 1989. Radial trends in cation ratios in tree rings as indicators of the impact of atmospheric deposition on forests. Can. J. For. Res. 19: 586-594.

Boyce, J.S. 1961. Forest Pathology. 3rd Ed. McGraw-Hill Book Co. Inc. New York, NY. 572 p

Browning, J.A. 1983. Whither plant pathology? Whither plant health? Plant Disease 67: 575-577.

Canadian Council of Forest Ministers. 1987. A National Forest Sector Strategy for Canada. Can. Council For. Ministers. Ottawa, Ont. $20 \mathrm{p}$.

Canadian Forestry Service. 1982. Forest Insect and Disease Conditions in Canada 1981. Compiled by T.E. Sterner and A.G. Davidson. Can. For. Serv. Ottawa, Ont. 46 p

Canadian Forestry Service. 1988. Program Plan 1988-1989. Nfld. For. Res. Centre, Can. For. Serv. St. John's Nfld. 235 p.

Canadian Institute of Forestry. 1989. Policy on integrated forestry pest management. For. Chron. 65:380-383

Chappelka, A.H. III, and B.I. Chevone. 1986. White ash seedling growth response to ozone and simulated acid rain. Can. J. For. Res. 16: 786-790.

Cowling, E.B. and J.G. Horsfall. 1980. Prologue: How plants defend themselves. Pages 1-16 In: Plant Disease, an Advanced Treatise. Vol. V. J.G. Horsfall and E.B. Cowling Eds. Academic Press. New York, N.Y. $534 p$

Dorworth, C.E. and J.Krywienczyk. 1975. Comparisons among isolates of Gremmeniella abietina by means of growth rate, conidia measurement, and immunogenic reaction. Can. J. Bot. 53: 2506-2525

Dorworth, C.E., D.P. Webb, J. Krywienczyk and D.M. McNamara. 1982. Comparisons between serologic and gas chromatographic techniques for characterization of Gremmeniella abietina and related species. Eur. J. For. Path. 12: 209-217.

Dorworth, C.E., J. Krywienczyk and D.D. Skilling. 1977. New York isolates of Gremmeniella abietina (Scleroderris lagerbergi) identical in immunogenic reaction to European isolates. Plant Dis. Rep. 61: 887-890.

Dumas, M.T. 1988. Biological species of Armillaria in the mixedwood forest or northern Ontario. Can. J. For. Res. 18: 872-874.

Forestry Canada. 1988. Canada's Forest Inventory 1986. For. Canada, Ottawa, Ont. $60 \mathrm{p}$. 
Furlan, V., J.A. Fortin, and C. Plenchette. 1983. Effects of different vascular-arbuscular mycorrhizal fungi on growth of Fraxinus americana. Can. J. For. Res. 13: 589-593.

Gross, H.L. 1985. White pine blister rust: a discussion of the disease and hazard zones for Ontario. Proc. Entomol. Soc. Ont. 116: $72-79$.

Hubbes, M. 1987. Influence of biotechnology on forest disease research and disease control. Can. J. Plant Pathol. 9: 343-348.

Hunt, R.S. 1983. White pine blister rust in British Columbia II. Can stands be hazard rated? For. Chron. 59: 30-33.

Hunt, R.S., E. von Rudloff, M.S. Lapp, and J.F. Manville. 1985. White pine blister rust in British Columbia III. Effects on the gene pool of western white pine. For. Chron. 61: 484-488

Kelman, A. 1987. The status of support for forest pathology research. Plant Disease. 71: 387

Lachance, D. 1979. Découverte de la souche européenne de Gremmeniella abietina au Québec. Phytoprotection 60: 168

Laflamme, G. 1988. Trial to control Scleroderris canker in red pine plantations. Pages 151-156 In. Recent Research on Scleroderris Canker of Conifers. Proceedings IUFRO Working Party S2.06-02. Sept. 1986. Austria. Mitteilungen der Forstlichen Bundesversuchsanstalt. Wien. Austria. Vol. 162. 167 p.

Laflamme, G. and D. Lachance. 1987. Large infection centre of Scleroderris canker (European Race) in Quebec Province. Plant Disease 71: 1041-1043.

Lavallée, A. 1986. Zones de vulnérabilité du pin blanc à la rouille vésiculeuse au Québec. For. Chron. 62: 24-28

Lockwood, J.L. 1985. Doctor of plant health degree and international programs: The Council Acts. Plant Disease 69: 547

Magasi, L.P. 1982. Forest insect and disease survey 1979, Maritimes Region. In: Forest Insect and Disease Survey, Annual Reports 1978 and 1979. Can. For. Serv. Ottawa, Ont. 1982. 90 p.

McKevlin, M.R., D.D. Hook, W.H. McKee Jr., S.V. Wallace and J.R. Woodruff. 1987. Loblolly pine seedling root anatomy and iron accumulation as affected by soil waterlogging. Can. J. For. Res. 17: 1257-1264
Morrisson, D.J., D. Chu and A.L. S. Johnson. 1985. Species of Armillaria British Columbia. Can. J. Plant Pathol. 7: 242-246.

Ouellette, G.B., N. Benhamou, N. Lecours and D. Lachance. 1988. Investigations on new means of identifying races of Ascocalyx abietina Pages 73-79 Im. Recent Research on Scleroderris Canker of Conifers. Proceedings IUFRO Working Party S2.06-02. Austria Sept. 1986. Mitteilungen der Forstlichen Bundesversuchsanstalt, Wien, Austria. Vol. 162. $167 \mathrm{p}$

Petrini, O., L.E. Petrini, G. Laflamme and G.B. Ouellette. 1989. Taxonomic position of Gremmeniella abietinaand related species: a reappraisal. Can. J. Bot. 67: 2805-2814.

Rishbeth, J. 1987. Forest pathology - present and future. Can. J. Plant Pathol. 9: 321-333

Sinclair, W.A. 1989. An editorial perspective on plant disease. Plant Disease 73: 3 .

Singh, P., C.E. Dorworth and D.D. Skilling. 1980. Gremmeniella abietina in Newfoundland. Plant Disease 64: 1117-1118.

Society of American Foresters. 1988. Healthy Forests, Healthy World Proc. National Convention October 19, 1988. Rochester, N.Y $424 p$

Tammen, J.F. and F.A. Wood. 1977. Education for the practitioner Pages 393-410. In: Plant Disease, and Advanced Treatise. Vol. I. J.G. Horsfall and E.B. Cowling eds. Academic Press, New York, N.Y. $465 \mathrm{p}$

Thorton, F.C., M. Schaedle and D.J. Raynald. 1986. Effect of aluminum on the growth of sugar maple in solution culture. Can J. For. Res. 16: 892-896.

Whitney, R.D. 1988. The hidden enemy, root rot technology transfer. Can. For. Serv. and Ont. Min. Nat. Resour. Ont. 35 p.

Whitney, R.D. 1989. Root rot damage in naturally regenerated stands of spruce and balsam fir in Ontario. Can. J. For. Res. 19 295-308.

Whitney, R.D., R.S. Hunt and J.A. Munro. 1983. Impact and control of forest diseases in Canada. For. Chron. 59: 223-228.

Whitney, R.S. and G.B. MacDonald. 1985. Effects of root rot on the growth of balsam fir. Can. J. For. Res. 15: 890-895.

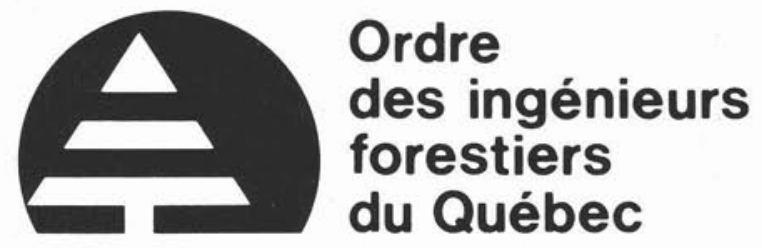

Le Genie Forestier: Une Profession Ouverte vers le Progres

\author{
Venez échanger avec les professionnels de la forêt \\ au kiosque de l'ordre
}

Union Internationale des Instituts de Recherches Forestières XIX Congrès Mondial 5-11 août, 1990, Montréal 